\title{
Biogas generation potential of anaerobic co-digestion of municipal solid wastes and livestock manures
}

\section{Fabíole Jordana Los Barbosa}

Environmental Engineering Department, Universidade Estadual do Centro-oeste (UNICENTRO),Irati, Brazil.84.500-000; fabiolelos@gmail.com

\author{
Alexandre Rodrigues Cabral \\ Dept. Civil Engineering, Université de Sherbrooke, Sherbrooke, QC, Canada J1K 2R1; \\ alexandre.cabral@usherbrooke.ca

\section{Marlon André Capanema} \\ Dept. of Sanitation and Environmental Engineering, Federal Institute of Goiás, \\ Goiânia, Brazil, 74055-110; marloncapanema@gmail.com \\ Waldir Nagel Schirmer* \\ (*) Corresponding author. Environmental Engineering Department, Universidade \\ Estadual do Centro-oeste (UNICENTRO), Irati, Brazil. Address: PR 153 Road, Km 07, \\ Riozinho Square, Irati, Parana State, Brazil, 84.500-000. Phone: 55 (42) 34213216; \\ wanasch@hotmail.com
}

\begin{abstract}
This study evaluated the potential of biogas generation of the fresh organic fraction of municipal solid wastes (OFMSW) inoculated with swine manure and cattle manure, based on the volatile solids content obtained from biochemical methane potential (BMP) tests. Several physico-chemical parameters (e.g. volatile solids, $\mathrm{pH}$ and chemical oxygen demand) were assessed in the laboratory before and after 50 days of incubation of several samples of OFMSW, swine manure and cattle manure, and mixtures thereof. During incubation, reductions in percentage of volatile solids were relatively low (from $5.5 \%$ to $11.4 \%$ ), indicating the existence of substrates that can degrade after the 50 -day digestion period. Among the physico-chemical parameters evaluated, $\mathrm{pH}$ was a limiting parameter for anaerobic digestion of OFMSW and manures. The mixture showing the best performance in terms of volume of biogas generated contained $1 g_{v s}$ OFMSW: $1 g_{v s}$ swine manure, which led to the production of $60.4 \mathrm{~mL} \mathrm{gVs}^{-1}$ or $22 \mathrm{~mL} \cdot \mathrm{gOFMSW}^{-1}$ biogas. The values of $\mathrm{CH}_{4}$ concentration increased throughout the incubation period, and the $\mathrm{CH}_{4}$ concentration value peaked at $80 \%$ for the mixture $1 \mathrm{~g}_{\mathrm{vs}}$ OFMSW: $1 \mathrm{~g}_{\mathrm{vs}}$ swine manure. The results obtained indicate the OFMSW and manures can be effectively used for power generation.
\end{abstract}

Barbosa, F.J.L., Cabral, A.R., Capanema, M.A. \# and Schirmer, W.N. \# (2018). Biogas Generation Potential of Anaerobic Co-Digestion of Municipal Solid Wastes and Livestock Manures. Journal of Solid Waste Technology and Management, 44(3): 248-258. 
Key-words: Biochemical methane potential (BMP); Co-digestion; Landfill; Methane production; Renewable energy.

\section{INTRODUCTION}

Many countries still rely strongly on energy from non-renewable sources such as oil, coal and natural gas (Sims et al., 2007; WEC, 2013). The growing shortage of such resources, the serious environmental impacts (e.g. greenhouse gas emissions, global warming, photochemical smog, etc.) and the high economic costs associated to these sources highlight the necessity to diversify the world energy matrix.

Biomass and organic solid residues represent a promising alternative of energy renewable source, which is economically interesting and meets the increasing demand for renewable fuels and sustainable development (WEC, 2013). According to the National System of Information on Water and Sanitation (Brasil, 2016), Brazil generated 55.9 million tons of municipal solid wastes (MSW) in 2014. From these, over $50 \%$ come from the organic fraction of municipal solid wastes (OFMSW). Regarding agroindustrial organic waste, this amount increases to over 740 million tons a year, including agriculture, livestock and silviculture wastes (Brasil, 2012).

Anaerobic digestion or degradation is considered a mature biotechnology which values organic waste for the production of biogas. It is a complex process which requires specific environmental conditions and different bacterial populations (Browne, Allen and Murphy, 2014; Lastella et al., 2002). The balance of an anaerobic treatment system can be reached by monitoring factors that influence the process such as $\mathrm{pH}$, temperature, moisture content, $\mathrm{C} / \mathrm{N}$ ratio, nutrients, substrate composition, and the presence of inhibitory substances (Abbasi, Tauseef and Abbasi, 2012; Schirmer et al., 2014; Yin et al., 2014; Zhang et al., 2014).

The anaerobic treatment of two or more types of organic wastes, i.e. anaerobic co-digestion, might improve the biodigestion process, when compared to single substrates (mono-digestion) (Álvarez, Otero and Lema, 2010; Mata-Alvarez et al., 2014). In anaerobic co-digestion, positive synergy interactions such as nutrient, moisture and toxic components dilution might occur (Mata-Alvarez et al., 2011). The most common substrates used in anaerobic biodigesters are sewage sludge (from wastewater treatment plants), animal manure, organic wastes from agriculture, OFMSW (from markets and households), food waste, etc. (Esposito et al., 2012a). The product of the anaerobic treatment is a biogas, mainly composed of methane $\left(\mathrm{CH}_{4}\right)$ and carbon 
dioxide $\left(\mathrm{CO}_{2}\right)$. In the case of landfills, the $\mathrm{CH}_{4}$ concentration can vary from 40 to $60 \%$, whereas $\mathrm{CO}_{2}$ concentrations are about 40\% (Cabral et al., 2010; Imre et al., 2009).

The biogas recovery to be used as energy generator requires the knowledge of the $\mathrm{CH}_{4}$ generation potential in different processes. The Biochemical Methane Potential (BMP) is a relatively simple test used to evaluate the biodegradability of the organic matter and the methane production potential from an organic waste (Owen et al., 1979). This test consists in the anaerobic incubation of a small fraction of the waste (substrate), usually inoculated (co-digestion) in specific conditions of moisture, $\mathrm{pH}$, nutrients and substrate:inoculum ratio (S:I), in order to produce biogas (Hansen et al., 2004; Labatut, Angenent and Scott, 2011; Owen et al., 1979; Schirmer et al., 2014). Several BMP studies have been carried out using different experimental conditions, which makes difficult the comparison between different studies on BMP from organic wastes. There are differences in the nature and amount of substrate and inoculum, bottles headspace volumes, headspace pressure, $\mathrm{pH}$ values, etc; as well as in the way the results are reported (Angelidaki et al., 2009; Esposito et al., 2012b).

This study aimed at determining the potential of biogas generation from fresh OFMSW, inoculated with swine manure and cattle manure, based on the volatile solids content. The study was carried out in bench anaerobic biodigesters suitable to the investigation of biochemical methane potential. Physico-chemical parameters were monitored prior and after the BMP tests, in order to verify the conditions of bacterial development that were favorable to the biogas generation.

This work is in accordance with waste valuation, through the recovery of organic solid wastes and biogas production. The huge amount of OFMSW and agroindustrial waste produced in Brazil and worldwide can be used as an alternative and renewable source for the production of electrical and thermal energy in a sustainable manner. Therefore, this report on BMP tests is an important contribution to this sector in the national and global scenery. Moreover, this study is also aligned with the recent global agreements regarding the reduction of greenhouse effect gases. 


\section{MATERIAL AND METHODS}

\subsection{Sampling, preparation and characterization of organic solid wastes, swine manure and cattle manure}

The organic fraction of municipal solid wastes (OFMSW) was collected from the municipal landfill in Guarapuava (Parana, Brazil), a town with a population of 167.3 thousand inhabitants whose average production of solid waste is 100 ton. $^{-1}$ (IBGE, 2002; Guarapuava, 2011). At the landfill, OFMSW was collected from the pile of urban solid waste deposited on the previous day and that had not been compacted or buried yet. Four portions from three different sections (top, middle and bottom) of the pile of waste were collected and homogenized according to the quartering technique described in the regulation NBR 10007 (ABNT, 2004). At the end, a total of $5.0 \mathrm{~kg}$ fresh OFMSW sample was collected. The inocula (swine and cattle manure) were collected from rural properties a day before the biodigester preparation. The amount of $5.0 \mathrm{~kg}$ of each type of manure was collected from places where the animals were confined and fed. The swine cattle were fed with processed meal, while the cows had a diet of processed meal, silage, haylage and brewery waste (barley).

In the laboratory, each sample of OFMSW, swine manure and cattle manure was homogenized separately using a blender, in order to reduce the granulometry and, consequently, increase the superficial area of samples during the tests. According to Abbasi, Tauseef e Abbasi (2012), larger superficial areas lead to an increase in the waste speed of degradation, due to the larger contact area between microorganisms and the waste. Then, the OFMSW samples were stored at $-20^{\circ} \mathrm{C}$. Prior to the preparation of biochemical methane potential (BMP) tests, the samples were defrosted at room temperature $\left(21^{\circ} \mathrm{C}\right)$ for 24 hours (Browne, Allen and Murphy, 2014; Browne and Murphy, 2013). The inocula were stored at $4^{\circ} \mathrm{C}$ for about 24 horas up to the biodigester preparation, following procedures described by Cabbai et al. (2013) and Wang et al. (2012).

A physico-chemical characterization was carried out in laboratory prior and after BMP tests, using the different samples (OFMSW, swine manure and cattle manure) and their mixtures at different ratios, as previously described. The physicochemical parameters evaluated were moisture content, volatile solids (VS), total solids (TS), pH, alkalinity, carbon (C), nitrogen (N), phosphorus (P) and chemical oxygen 
demand (COD), according to the Standard Methods for the Examination of Water and Wastewater (APHA, 1999).

\subsection{Preparation and startup of BMP tests}

To evaluate the biodegradability of the organic matter and the methane $\left(\mathrm{CH}_{4}\right)$ generation potential through the BMP tests, samples were placed in 250-mL borosilicate bottles (biodigesters) with a screw cap equipped with a valve for gas release, and a pressure gauge to read the internal pressure of the bottles. The samples were tested in batch mode according to the following ratios (substrate:inoculum): $1 \mathrm{~g}_{\mathrm{vs}}$ OFMSW: $1 \mathrm{~g}_{\mathrm{vs}}$ swine manure; $1 \mathrm{~g}_{\mathrm{vs}}$ OFMSW:1 $\mathrm{g}_{\mathrm{vs}}$ cattle manure; and 3 $\mathrm{g}_{\mathrm{vs}}$ OFMSW: $1 \mathrm{~g}_{\mathrm{vs}}$ cattle manure. Each mixture (proportion) was tested in triplicate resulting in 9 bottles. The blanks were composed of inocula (swine and cattle manure) and were also evaluated in triplicate, resulting in 6 blank bottles. The addition of water was necessary to correct moisture at $85 \%$, as recommended by Andreoli et al. (2003) and USEPA (1991), so that all biodigesters had the same moisture experimental conditions. All the samples were homogenized in order to increase the interaction between substrate and inoculum.

After filling up each biodigester, a current of nitrogen gas $\left(\mathrm{N}_{2}\right)$ was circulated in the bottle headspace for 5 minutes in order to guarantee the medium anaerobic conditions (Mshandete et al., 2004). Incubation of the biodigesters was carried out in thermostatic bath at $32^{\circ} \mathrm{C}$ constant temperature for 50 days.

\subsection{Monitoring the biogas generation}

The monitoring of the biogas generated was based on the daily variations of the internal pressures of the biodigesters in relation to the atmospheric pressure. The internal values were obtained through the reading of pressure gauges coupled to the biodigesters, which were then converted in biogas volume at standard temperature and pressure $(\mathrm{STP})$ conditions, according to the ideal gas law $(\mathrm{PV}=\mathrm{nRT})$, where $\mathrm{P}=$ absolute pressure measured by the pressure gauges; $\mathrm{V}=$ biogas volume; $\mathrm{T}=$ biogas temperature; and $\mathrm{R}=$ universal gas constant (Labatut, Angenent and Scott, 2011). Data related to times of atmospheric pressure were obtained from the Weather System of Parana State data base. The volume of biogas generated only by the OFMSW was 
calculated by subtracting the volume of biogas generated in the blanks, which only contained inoculum, as described by Angelidaki et al. (2009) and Owen et al. (1979).

The concentration of gases $\mathrm{CH}_{4}, \mathrm{CO}_{2}$ and hydrogen sulphide $\left(\mathrm{H}_{2} \mathrm{~S}\right)$ was measured on the $3^{\text {rd }}$ and $50^{\text {th }}$ days of BMP tests, according to the gas accumulation generated in the headspace of biodigesters. The biogas was collected in Tedlar ${ }^{\circledR}$ bags, suitable for gas sampling, and analyzed in triplicate using a portable analysis kit (from EMBRAPA Suínos e Aves and Alfakit Ltda, Brazil). $\mathrm{CH}_{4}$ and $\mathrm{CO}_{2}$ concentrations were analyzed through the volume difference method which involves selective absorption and oxidation, while the $\mathrm{H}_{2} \mathrm{~S}$ concentration was analyzed through the colorimetric test.

\section{RESULTS AND DISCUSSION}

\subsection{Physico-chemical characterization of OFMSW and inocula}

Table 1 presents the average values of the triplicates of the OFMSW and swine manure and cattle manure physico-chemical characterization parameters as used in this study.

Table 1: Physico-chemical characterization of OFMSW, swine manure and cattle manure.

\begin{tabular}{cccc}
\hline Parameter & OFMSW & Swine manure & Cattle manure \\
\hline Moisture content $(\%)$ & $* 82.5 \pm 0.5$ & $73.2 \pm 0.6$ & $84.7 \pm 0.3$ \\
VS (\%Ts) & $93.1 \pm 0.3$ & $85.6 \pm 0.5$ & $88.6 \pm 2.5$ \\
COD (g.kg $\left.{ }^{-1}\right)$ & $190.1 \pm 9.8$ & $74.0 \pm 1.3$ & $91.4 \pm 8.7$ \\
pH & $4.7 \pm 0.2$ & $6.5 \pm 0.1$ & $6.4 \pm 0.2$ \\
C (\%) & $45.6 \pm 0.9$ & $40.6 \pm 0.4$ & $29.4 \pm 0.06$ \\
N (\%) & $2.0 \pm 0.02$ & $3.2 \pm 0.01$ & $2.0 \pm 0.01$ \\
C $/ \mathrm{N}$ & $23 / 1$ & $13 / 1$ & $15 / 1$ \\
\hline
\end{tabular}

*Average \pm standard deviation.

It is known that in Brazil, considering local characteristics and population habits, the MSW moisture content is around 40 and 60\% (IBAM, 2001). In this study, as the organic fraction retains more water when compared to the MSW total mass, the moisture content of the OFMSW collected from the Guarapuava landfill was relatively high $(=82.5 \%)$. This value is at the same level of the moisture content measured for the 
swine and cattle manure $(=73.2 \%$ and $84.7 \%$, respectively), and close to the $76 \%$ obtained from organic waste by Crovador (2014), in the same landfill under study.

One parameter employed to measure biodegradability of waste is volatile solids (Redon et al., 2005). In this study, the OFMSW was collected before the waste had been through degradation processes in the landfill. Likewise, the animal manure was collected from the places where the animals were confined and fed, before being treated and disposed. As a consequence, both the OFMSW (VS=93.1\%) and the inocula (swine manure $\mathrm{VS}=85.6 \%$ and cattle manure $\mathrm{VS}=88.6 \%$ ) presented high biodegradability potential in terms of volatile solids. According to Kelly (2002) and Decottignies et al. (2005), samples can be considered stabilized (degraded) when they present below $20 \%$ volatile solids. Another parameter which reflects, even if indirectly, the OFMSW biodegradability in terms of organic matter is the chemical oxygen demand (COD). It is known that one part of organic matter expressed in terms of COD can be biologically converted. The OFMSW organic matter content averaged $190.1 \mathrm{~g}^{\mathrm{kg}} \mathrm{kg}^{-1}$, while this content in swine manure averaged $74.0 \mathrm{~g} . \mathrm{kg}^{-1}$ and in cattle manure was $91.4 \mathrm{~g}^{\mathrm{kg}} \mathrm{kg}^{-1}$.

The OFMSW presented lower $\mathrm{pH}$ (average $\mathrm{pH}=4.7$ ) when compared to the manures under analysis (Table 1). Initially, still in the waste stowage phase, which precedes the collection and final disposal, the initial degradation of the waste occurred, mainly at temperatures above $25^{\circ} \mathrm{C}$. During the period it was stowed, the waste started to degrade due to the presence of ubiquitous bacteria and fungi (Alcântara, 2007; Tchobanoglous, Theisen and Vigil, 1993), resulting in a $\mathrm{pH}$ value below neutrality. In addition, the waste composition, e.g. waste containing acid, might have influenced the OFMSW pH.

The OFMSW presented higher carbon content $(\mathrm{C}=45.6 \%)$ when compared to the swine manure $(\mathrm{C}=40.6 \%)$ and cattle manure $(29.4 \%)$, mainly due to the presence of vegetable and plant remains in the waste mass, and because these remains had not been digested yet. As a consequence, the OFMSW presented a relatively higher average value for the $\mathrm{CN}$ ratio $(\mathrm{C} / \mathrm{N} \sim 23 / 1)$. Such value was close to the numbers reported by Hessami, Christensen and Gani (1996) for the biodigestion process (between 25/1 and 30/1). Moreover, there was higher presence of $\mathrm{N}$ in swine manure when compared to OFMSW due to the ammonia $\left(\mathrm{NH}_{3}\right)$ released in the animal metabolic processes and the nutritive substances included in the animal food. According to Mata-Alvarez et al. (2011), manures tend to present high $\mathrm{N}$ content. Therefore, $\mathrm{C} / \mathrm{N}$ ratios in swine manure and cattle manure was approximately 13 and 15, respectively (Table 1). 


\subsection{BMP tests: initial and final physico-chemical characterization of biodigesters}

Table 2 presents the initial and final physico-chemical characterization of OFMSW biodigesters inoculated with swine and cattle manure, during the 50-day BMP tests. The values correspond to the average of triplicates carried out \pm standard deviation.

Table 2: Initial and final physico-chemical characterization of biodigesters.

\begin{tabular}{|c|c|c|c|c|c|c|}
\hline \multirow{2}{*}{ Biodigesters } & \multicolumn{2}{|c|}{$\begin{array}{l}1 \mathrm{~g}_{\mathrm{vs}} \text { OFMSW: } 1 \mathrm{~g}_{\mathrm{vs}} \\
\text { swine manure }\end{array}$} & \multicolumn{2}{|c|}{$\begin{array}{c}1 \mathrm{~g}_{\mathrm{vs}} \text { OFMSW: } 1 \mathrm{~g}_{\mathrm{vs}} \\
\text { cattle manure }\end{array}$} & \multicolumn{2}{|c|}{$\begin{array}{l}3 \mathrm{~g}_{\mathrm{vs}} \text { OFMSW: } 1 \mathrm{~g}_{\mathrm{vs}} \\
\text { cattle manure }\end{array}$} \\
\hline & Initial & Final & Initial & Final & Initial & Final \\
\hline Moisture (\%) & $87.0 \pm 0.2$ & $\begin{array}{l}90.1 \\
\pm 0.4\end{array}$ & $83.9 \pm 0.1$ & $86.9 \pm 1.3$ & $83.4 \pm 0.3$ & $86.6 \pm 0.2$ \\
\hline $\operatorname{COD}\left(\mathrm{g} \cdot \mathrm{L}^{-1}\right)$ & $68.8 \pm 15.8$ & $23.7 \pm 5.7$ & $175.0 \pm 16.3$ & $\begin{array}{c}17.8 \pm \\
0.02\end{array}$ & $\begin{array}{l}167.6 \\
\pm 17.8 \\
\end{array}$ & $13.7 \pm 0.03$ \\
\hline VS (\%тs) & $88.6 \pm 2.5$ & $\begin{array}{l}83.7 \\
\pm 0.1 \\
\end{array}$ & $\begin{array}{r}83.5 \\
\pm 0.9 \\
\end{array}$ & $74.9 \pm 13.4$ & $90.0 \pm 0.2$ & $79.8 \pm 0.5$ \\
\hline $\mathrm{pH}$ & $6.0 \pm 0.04$ & $\begin{array}{c}5.3 \\
\pm 0.08 \\
\end{array}$ & $\begin{aligned} & 6.1 \\
& \pm 0.05 \\
&\end{aligned}$ & $\begin{aligned} & 4.6 \\
& \pm 0.02 \\
&\end{aligned}$ & $\begin{array}{l}5.6 \\
\pm 0.05 \\
\end{array}$ & $\begin{array}{r}3.9 \\
\pm 0.3 \\
\end{array}$ \\
\hline $\begin{array}{l}\text { Alkalinity } \\
\left(\mathrm{g}_{\mathrm{CaCO} 3} \cdot \mathrm{L}^{-1}\right)\end{array}$ & $\begin{aligned} & 4.0 \\
& \pm 0.05 \\
&\end{aligned}$ & $\begin{array}{c}5.0 \\
\pm 0.03 \\
\end{array}$ & $\begin{array}{c}2.5 \\
\pm 0.02 \\
\end{array}$ & $\begin{array}{r}1.5 \\
\pm 0.5 \\
\end{array}$ & $\begin{array}{l}1.3 \\
\pm 0.03 \\
\end{array}$ & $* \mathrm{NE}$ \\
\hline $\mathrm{P}\left(\mathrm{g} \cdot \mathrm{L}^{-1}\right)$ & $\begin{array}{c}3.34 \\
\pm 0.6 \\
\end{array}$ & $\begin{array}{c}0.80 \\
\pm 0.08 \\
\end{array}$ & $\begin{array}{r}1.14 \\
\pm 0.1 \\
\end{array}$ & $\begin{array}{c}0.21 \\
\pm 0.01 \\
\end{array}$ & $\begin{array}{c}0.94 \\
\pm 0.01 \\
\end{array}$ & $\begin{array}{c}0.20 \\
\pm 0.01 \\
\end{array}$ \\
\hline $\mathrm{C}(\%)$ & $42.4 \pm 0.13$ & $\begin{array}{c}33.9 \\
\pm 0.02\end{array}$ & $44.2 \pm 0.04$ & $\begin{array}{c}36.8 \pm \\
0.04\end{array}$ & $\begin{array}{l}44.6 \pm \\
0.03\end{array}$ & $\begin{array}{c}28.5 \pm \\
0.24\end{array}$ \\
\hline N (\%) & $\begin{array}{c}3.0 \\
\pm 0.11\end{array}$ & $\begin{array}{c}2.5 \\
\pm 0.10\end{array}$ & $\begin{array}{c}2.2 \\
\pm 0.02\end{array}$ & $\begin{array}{l}1.9 \\
\pm 0.05\end{array}$ & $\begin{array}{c}2.2 \\
\pm 0.11\end{array}$ & $\begin{array}{c}2.1 \\
\pm 0.03\end{array}$ \\
\hline $\mathrm{C} / \mathrm{P}$ & $13 / 1$ & $42 / 1$ & $39 / 1$ & $175 / 1$ & $47 / 1$ & $142 / 1$ \\
\hline $\mathrm{C} / \mathrm{N}$ & $14 / 1$ & $14 / 1$ & $20 / 1$ & $19 / 1$ & $20 / 1$ & $14 / 1$ \\
\hline
\end{tabular}

*NE: not evaluated

As previously reported, in order to keep moisture around $85 \%$, it was necessary to add water to all biodigesters. According to Andreoli et al. (2003) and USEPA (1991), the moisture around 60 to $90 \%$ is considered ideal for the anaerobic digestion by microorganisms. At the end of the BMP tests, an increase of $\sim 3 \%$ moisture in the biodigesters was noticed, which is the result of the water release at the end of the anaerobic digestion phases.

The COD, which measures indirectly the amount of organic matter present in the biodigesters, presented high percentage of reduction, with $66 \%$ for the mixture $1 \mathrm{~g}_{\mathrm{vs}}$ 
OFMSW: $1 g_{v s}$ swine manure, 90\% for the mixture $1 g_{v s}$ OFMSW: $1 g_{v s}$ cattle manure, and $92 \%$ for the mixture $3 g_{v s}$ OFMSW: $1 g_{v s}$ cattle manure (Table 2). Such percentages of reduction are in part due to the organic matter degradation by microorganisms in the biodigesters. Zhang et al. (2008) pointed out that a soluble COD represents the organic matter available to the bacteria in the $\mathrm{CH}_{4}$ and $\mathrm{CO}_{2}$ (biogas) production. The mixtures containing OFMSW and cattle manure obtained higher initial COD values, probably due to the higher COD concentration in cattle manure when compared to the swine manure (Table 1). The percentages of COD reduction are close to those found by Schirmer et al. (2014), whose COD reduction was $88.3 \%$ in the COD of fresh organic waste inoculated with sewage sludge, for 80 days of incubation in mesophilic conditions.

Regarding volatile solids (VS) content, all biodigesters presented high biodegradation potential, evidenced by the high initial content of volatile solids, which varied from $83.5 \% \mathrm{Ts}$ to $90 \% \mathrm{Ts}$. These values were higher than those reported by Crovador (2014), Schirmer et al. (2014) and Barcelos (2009), which ranged between $65 \%$ Ts and $82 \%$ Ts. The percentages of reduction of volatile solids were $5.5 \%$ for the mixture $1 \mathrm{~g}_{\mathrm{vs}}$ OFMSW: $1 \mathrm{~g}_{\mathrm{vs}}$ swine manure, $10.3 \%$ for the mixture $1 \mathrm{~g}_{\mathrm{vs}}$ OFMSW: $1 \mathrm{~g}_{\mathrm{vs}}$ cattle manure, and $11.4 \%$ for the mixture $3 g_{v s}$ OFMSW: $1 g_{v s}$ cattle manure (Table 2). It seems relevant to observe that the reduction of this parameter was relatively small, indicating the existence of substrate which can be degraded and, therefore, the generation of biogas even after 50 days of digestion, as considered in this study. For waste from the same landfill under study, Crovador (2014) obtained volatile solids reduction around $15.4 \%$ after 91 days of BMP test, lower than the values close to $47 \%$ found by other authors (Schirmer et al., 2014; Barcelos, 2009).

The initial $\mathrm{pH}$ for the treatments under evaluation was close to the neutrality necessary for the start-up of biodigesters (Table 2). In this sense, the advantage of mixing a substrate (organic waste) with an inoculum (manure) to obtain a $\mathrm{pH}$ value close to neutrality is evidenced, mainly when dealing with an organic waste with relatively low $\mathrm{pH}$. According to O'Leary and Tchobanoglous (2002), during the anaerobic digestion there is reduction in the medium $\mathrm{pH}$ caused by the formation of organic acids (acidogenesis) and high concentration of $\mathrm{CO}_{2}$. In the methanogenic phase, acids and gaseous hydrogen are converted into $\mathrm{CH}_{4}$ and $\mathrm{CO}_{2}$, naturally increasing the medium $\mathrm{pH}$ up to values close to neutrality. Thus, the final stage of anaerobic digestion should be characterized by neutral or slightly alkaline $\mathrm{pH}$. In this study, at the end of 50 
days of digestion, $\mathrm{pH}$ values lower than the neutrality were obtained in all treatments under evaluation $(3.9 \leq \mathrm{pH} \leq 5.25$; Table 2$)$. The formation of VFA (volatile fatty acids) and consequent decrease in the medium $\mathrm{pH}$ might have inhibited the complete conversion of organic matter into biogas. Indeed, the presence of organic matter that could be degraded was verified according to the volatile solids data at the end of the BMP tests (Table 2). However, even with the medium acidification, the percentage of COD reduction (i.e. organic matter) reached values around 92\%. In anaerobic codigestion reactors, the $\mathrm{pH}$ must be monitored throughout the time to identify possible reduction in the $\mathrm{pH}$ value that might hamper the action of bacteria in the methanogenic phase and the degradation of organic waste.

One parameter that can be related to the $\mathrm{pH}$ is the alkalinity, to which the system buffer ability refers to and is represented by the balance between $\mathrm{CO}_{2}$ and bicarbonate ions during the anaerobic digestion (Ward et al., 2008; Sakar, Yetilmezsoy and Kocak, 2009). Regarding waste with low nitrogen content, bicarbonate alkalinity is the main way of keeping the system stability, due to the $\mathrm{pH}$ reduction as a function of the VFA presence (Georgacakis et al., 1982). According to Tchobanoglous, Theisen and Vigil (1993) and Lapp et al. (1975), the digestion occurs satisfactorily if the alkalinity is normally situated between 1.0 and $5.0 \mathrm{~g}_{\mathrm{CaCO}} \cdot \mathrm{L}^{-1}$, a band which comprises the initial and final values of the three treatments under evaluation in this study (Table 2).

During the 50 days of BMP tests, a sharp reduction in $\mathrm{P}$ content in the biodigesters was observed, and the percentages of reduction were $76 \%$ for the mixture 1 $\mathrm{g}_{\mathrm{vs}}$ OFMSW:1 $\mathrm{g}_{\mathrm{vs}}$ swine manure, $81.6 \%$ for the mixture $1 \mathrm{~g}_{\mathrm{vs}}$ OFMSW:1 $\mathrm{g}_{\mathrm{vs}}$ cattle manure, and $78.7 \%$ for the mixture $3 g_{v s}$ OFMSW: $1 g_{v s}$ cattle manure (Table 2 ). At the end, the biodigesters with OFMSW and cattle manure presented a $\mathrm{C} / \mathrm{P}$ relation over $100 / 1$, and final $\mathrm{P}$ concentrations equal to 0.2 g. $\mathrm{L}^{-1}$. The biodigester containing OFMSW and swine manure presented a 42/1 C/P relation, and final $\mathrm{P}$ concentrations equal to 0.8 g. $\mathrm{L}^{-1}$. According to Souza (1984), the ideal amount of $\mathrm{P}$ content for the anaerobic digestion is one that satisfies the $\mathrm{C} / \mathrm{P} \leq 100$ relation, evidencing the high consumption of phosphorus during the anaerobic digestion in the 50 days under evaluation.

The reductions in $\mathrm{C}$ and $\mathrm{N}$ concentrations were smaller when compared to those obtained for the P content. For example, the mixture $1 \mathrm{~g}_{\mathrm{vs}}$ OFMSW: $1 \mathrm{~g}_{\mathrm{vs}}$ swine manure presented $20 \% \mathrm{C}$ and $16.4 \% \mathrm{~N}$ reduction, while the mixture $1 \mathrm{~g}_{\mathrm{vs}}$ OFMSW: $1 \mathrm{~g}_{\mathrm{vs}}$ cattle manure presented $16.7 \% \mathrm{C}$ and $13 \% \mathrm{~N}$ reduction, and the mixture $3 \mathrm{~g}_{\mathrm{vs}}$ OFMSW: $1 \mathrm{~g}_{\mathrm{vs}}$ 
cattle manure obtained a $36 \% \mathrm{C}$ but only $5 \% \mathrm{~N}$ reduction. While carbon is an energy source for the microbial population, nitrogen caters for the protein needs for the microbial population growth (Igoni et al., 2008; Richard, 1992). In this study, the highest percentage of carbonaceous matter reduction was obtained for the mixture whose OFMSW proportion was the highest, i.e. $3 \mathrm{~g}_{\mathrm{vs}}$ OFMSW: $1 \mathrm{~g}_{\mathrm{vs}}$ cattle manure.

It's important to highlight that anaerobic co-digestion using OFMSW mixed with animal manure might compensate the differences of $\mathrm{N}$ content, keeping a balance of nutrients which is suitable to the methanogenic bacteria. At the end of 50 days of BMP tests, the $\mathrm{C} / \mathrm{N}$ ratio varied from $14 / 1$ to $19 / 1$ for the mixtures evaluated (Table 2). Such values are relatively low, since the $\mathrm{C} / \mathrm{N}$ ratio considered optimal for the anaerobic digestion is around 25/1 and 30/1, as reported by Hessami, Christensen and Gani (1996). In this case, $\mathrm{C} / \mathrm{N}$ ratio values below optimal band reveal a high degradation of the carbonaceous organic matter throughout the 50 days of tests.

The different characteristics presented by the OFMSW and the manures evidenced the possibility of synergy when carrying out anaerobic co-digestion. According to Mata-Alvarez, Macé and Llabrés (2000), the synergy interactions between substrates with improvement of moisture content and nutrients in the medium, lead to an increase in the production of biogas (discussed in sections 3.3 and 3.4). Also, if the characteristics of waste, individually, are not enough for the desired treatment, for example, too much carbon or too low $\mathrm{pH}$, the anaerobic digestion process might be improved by the mixture of different materials (Alcaya and Demirer, 2011).

\subsection{Biogas generation: quantitative results}

The total volume accumulated of biogas produced in each mixture in the biodigesters is presented in Figure 1, and was obtained through the sum of daily biogas production throughout the 50 days of BMP tests. The average of the volume generated in triplicates for each treatment (mixture) was calculated daily. The average biogas volume generated in the blank assays was also subtracted. 


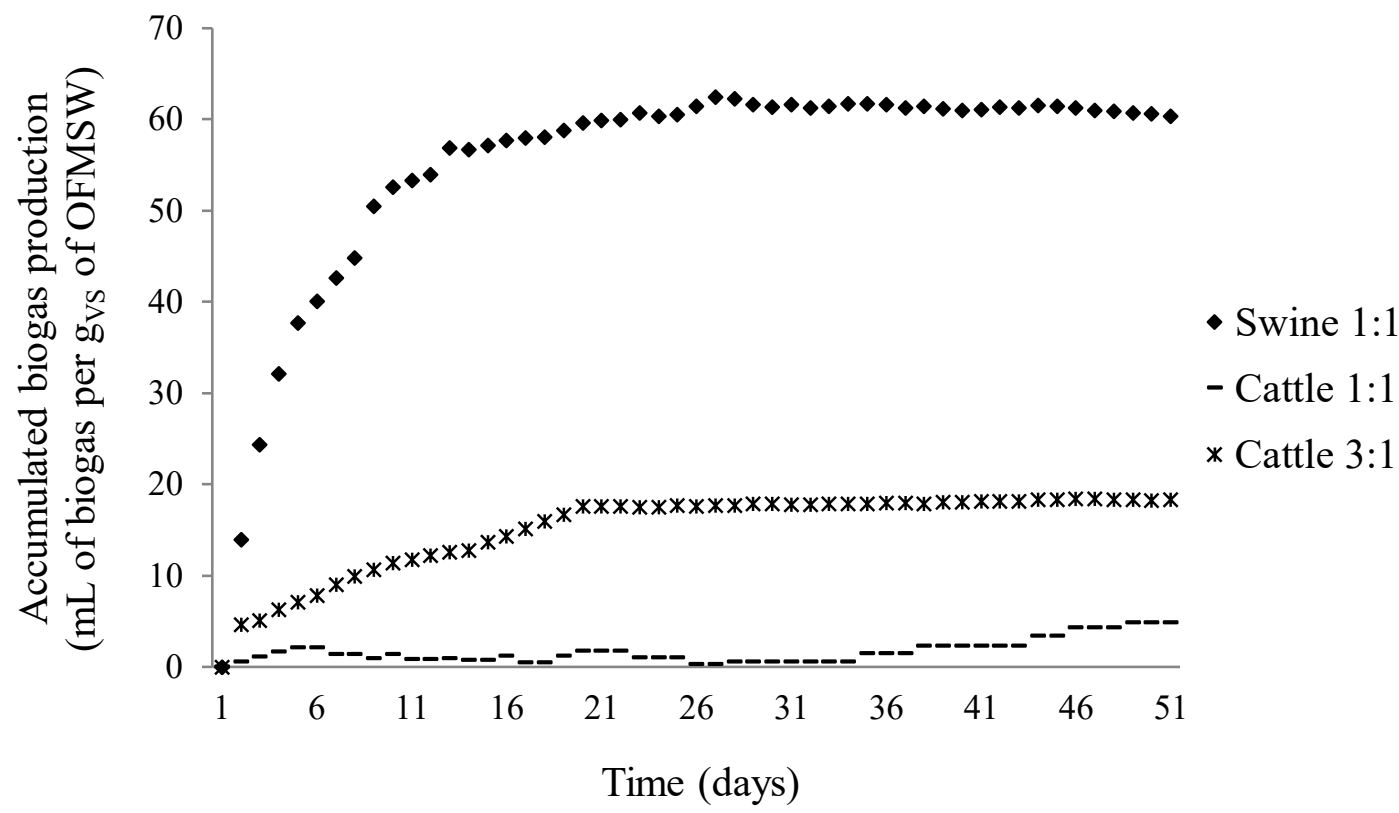

Figure 1: Volume of biogas accumulated per gram of OFMSW VS in the STP (mL.gvs${ }^{1}$ ) for the three treatments under evaluation.

The biogas generation was quite representative on the first few days of digestion. On the first day of the BMP test, the mixture $1 \mathrm{~g}_{\mathrm{vs}}$ OFMSW: $1 \mathrm{~g}_{\mathrm{vs}}$ swine manure reached a generation peak of $14 \mathrm{~mL} \mathrm{~g}_{\mathrm{Vs}}{ }^{-1}$ biogas. The mixture $3 \mathrm{~g}_{\mathrm{vs}}$ OFMSW: 1 $\mathrm{g}_{\mathrm{vs}}$ cattle manure, presented a maximum daily value of $4.6 \mathrm{~mL} \cdot \mathrm{gvs}^{-1}$, also on the first day of test. Other studies have also reported a trend of higher biogas generation on the first days of digestion in the BMP test. Parawira et al. (2004) observed that this high biogas production on the first days might be related to the easily degradable substances present in the substrate. The biogas generation curve increased steadily up to the $15^{\text {th }}$ day of BMP tests, after that the biogas generation daily rate became stable, with daily values of $<2.0 \mathrm{~mL} \cdot \mathrm{gVs}^{-1} \cdot \mathrm{d}^{-1}$ for the three mixtures under evaluation, resulting in the plateau observed in the curves presented in Figure 1. The mixture $1 \mathrm{~g}_{\mathrm{vs}}$ OFMSW: $1 \mathrm{~g}_{\mathrm{vs}}$ cattle manure obtained the lowest peak of biogas daily generation with $<2.0 \mathrm{~mL}$. $\mathrm{gvs}^{-1}$. $\mathrm{d}^{-}$ 1 .

It is difficult to compare different curves of biogas generation found in the literature, due to the different kind of experiments developed, which lead to results expressed in different units (Angelidaki et al., 2009). Hansen et al. (2004), when performing the anaerobic digestion of organic solid waste in thermophilic conditions $\left(55^{\circ} \mathrm{C}\right)$, also for a period of 50 days, identified that $80-90 \%$ of methane potential production was obtained in the first 10 days of digestion. Schirmer et al. (2014) evaluated the co-digestion of OFMSW from Recife (Brazil) with sewage sludge with 
the 1:50 ratio, at $35^{\circ} \mathrm{C}$, for a period of 80 days, and observed that the highest generation peaks were reached on the first 5 days of digestion. El-Mashad and Zhang (2010) reported that around 90 and $95 \%$ of the total biogas generated occurred on the first 20 days of digestion, in an anaerobic co-digestion experiment with food waste and dairy manure, in mesophilic conditions throughout 30 days. Finally, Cabbai et al. (2013) evaluated the biodigestion of OFMSW from canteens, supermarkets, restaurant, household, bakery, and fruit and vegetable markets for 30 days, also at mesophilic temperatures $\left(37^{\circ} \mathrm{C}\right)$ in single substrates and co-digestion regimes. Most of the volume of biogas generated was also on the first few days of the experiment. Depending on the conditions of the BMP test and the type of waste, the stabilization of biogas generation might be reached in a longer period, as observed by Xie et al. (2011), who obtained a plateau in the accumulated production of $\mathrm{CH}_{4}$ after a period of 60 days of BMP tests, with five different mixtures of swine manure and grass silage in mesophilic conditions.

The biogas production throughout the 50 days as a function of the substrate evaluated is presented in Table 3. After 50 days, the mixture with the highest volume of accumulated biogas was $1 \mathrm{~g}_{\mathrm{vs}}$ OFMSW:1 $\mathrm{g}_{\mathrm{vs}}$ swine manure (Table 3), with $60.4 \mathrm{~mL} . \mathrm{g}_{\mathrm{vs}}{ }^{-}$ ${ }^{1}$ (or $22 \mathrm{~mL} \mathrm{~g}_{\mathrm{OFMSW}}{ }^{-1}$ ). The mixture $3 \mathrm{~g}_{\mathrm{vs}}$ OFMSW: $1 \mathrm{~g}_{\mathrm{vs}}$ cattle manure accumulated 18.4 $\mathrm{mL} \cdot \mathrm{gvs}^{-1}$ (or $3.1 \mathrm{~mL}^{-g_{O F M S W}}{ }^{-1}$ ) and, finally, the mixture $1 \mathrm{~g}_{\mathrm{vs}}$ OFMSW:1 $\mathrm{g}_{\mathrm{vs}}$ cattle manure accumulated only $4.8 \mathrm{~mL} \cdot \mathrm{gVs}^{-1}$ (or $0.6 \mathrm{~mL} \mathrm{~g}_{\mathrm{OFMSW}}{ }^{-1}$ ). According to Table 2 , higher COD values did not result in higher volume of biogas generated. For example, the COD value of the mixture containing OFMSW and swine manure was lower when compared to the two mixtures containing OFMSW and cattle manure; however, the volume of biogas generated was higher. Also, the mixture containing OFMSW and swine manure was the one obtaining the lowest percentage of reduction of VS $(=5.5 \%)$. The highest volume generated by this mixture is due to the $14 \mathrm{~mL} \cdot \mathrm{gVs}^{-1}$ biogas peak obtained on the first day of the BMP test.

One parameter that might have contributed to the higher volume of biogas generated in the biodigesters containing OFMSW and swine manure was the $\mathrm{pH}$, which was closer to neutrality at the end of 50 days, when comparing to the mixtures containing OFMSW and cattle manure. Barcelos (2009) also verified a higher biogas generation using swine manure as inoculum and comparing it to cattle manure. 
Table 3: Biodigesters biogas production throughout the 50 days of digestion for the treatments under analysis.

\begin{tabular}{c|c|c|c}
\hline Biodigesters & $\begin{array}{c}1 \mathrm{~g}_{\mathrm{vs}} \\
\text { OFMSW:1 } \\
\mathrm{g}_{\mathrm{vs}} \text { swine } \\
\text { manure }\end{array}$ & $\begin{array}{c}3 \mathrm{~g}_{\mathrm{vs}} \\
\text { OFMSW:1 } \\
\mathrm{g}_{\mathrm{vs}} \text { cattle } \\
\text { manure }\end{array}$ & $\begin{array}{c}1 \mathrm{~g}_{\mathrm{vs}} \\
\text { OFMSW:1 } \\
\mathrm{g}_{\mathrm{vs}} \text { cattle } \\
\text { manure }\end{array}$ \\
\hline Gross accumulated biogas generation $(\mathrm{mL})$ & 472.0 & 221.2 & 127.2 \\
\hline $\begin{array}{c}\text { Blank assays accumulated biogas generation } \\
(\mathrm{mL})\end{array}$ & 93.8 & 38.7 & 95.7 \\
\hline Net accumulated biogas generation $(\mathrm{mL})$ & 378.2 & 182.5 & 31.5 \\
\hline Net accumulated biogas generation per g of & 60.4 & 18.4 & 4.8 \\
\hline waste VS (mL.g $\left.{ }_{\mathrm{vs}}{ }^{-1}\right)$ & 22.0 & 3.1 & 0.6 \\
\hline
\end{tabular}

Moreover, the presence of inhibitor agents in the biodigesters might be one of the causes of low biogas production, since they include recalcitrant or toxic materials present in the manures, such as ammonia (or its excess), sulphide, heavy metals and light metal ions, such as $\mathrm{Na}, \mathrm{K}, \mathrm{Mg}, \mathrm{Ca}$, and $\mathrm{Al}$ (Esposito et al., 2012b; Chen et al., 2014; Chen, Cheng and Creamer, 2008; Karhadkar et al., 1987; Rajagopal, Massé and Singh, 2013; Yenigün and Demirel, 2013; Siles et al., 2010). According to MataAlvarez et al. (2014), the presence of these compounds originates in the commercialized food or additives used to feed the animals, which promote high growth rates and prevent the cattle diseases. In this study, no analysis of potentially inhibiting or toxic compounds was carried out.

\subsection{Biogas characterization: determination of $\mathrm{CH}_{4}, \mathrm{CO}_{2}$ and $\mathrm{H}_{2} \mathrm{~S}$ concentrations}

The frequency of collection and characterization of the biogas depended on its accumulation inside the biodigesters. As most of the biogas generation occurred in the first week of digestion, an initial characterization was carried out on the $3^{\text {rd }}$ day. At the end of the digestion period ( $50^{\text {th }}$ day), another characterization was carried out. The biodigesters containing the mixture $1 \mathrm{~g}_{\mathrm{vs}}$ OFMSW:1 $\mathrm{g}_{\mathrm{vs}}$ swine manure allowed an intermediary characterization $\left(10^{\text {th }}\right.$ day), due to the higher biogas production in these reactors. The $\mathrm{CH}_{4}, \mathrm{CO}_{2}$ and $\mathrm{H}_{2} \mathrm{~S}$ concentrations are shown in Table 4. These values correspond to the average of the triplicates analyzed. 
Table 4: Average $\mathrm{CH}_{4}, \mathrm{CO}_{2}$ and $\mathrm{H}_{2} \mathrm{~S}$ concentration regarding the treatments employed.

\begin{tabular}{c|ccc|cc|cc}
\hline \multirow{2}{*}{ Biodigesters } & \multicolumn{2}{|c|}{$1 \mathrm{~g}_{\mathrm{vs}}$ OFMSW:1 $\mathrm{g}_{\mathrm{vs}}$ swine manure } & \multicolumn{2}{|c|}{$\begin{array}{c}1 \mathrm{~g}_{\mathrm{vs}} \text { OFMSW:1 } \mathrm{g}_{\mathrm{vs}} \\
\text { cattle manure }\end{array}$} & \multicolumn{2}{|c}{$\begin{array}{c}3 \mathrm{~g}_{\mathrm{vs}} \text { OFMSW:1 } \\
\text { cattle manure }\end{array}$} \\
\cline { 2 - 8 } & Day 3 & Day 10 & Day 50 & Day 3 & Day 50 & Day 3 & Day 50 \\
\hline $\mathrm{CH}_{4}(\%)$ & 60 & 65 & 80 & 60 & 69 & 58 & 65 \\
\hline $\mathrm{CO}_{2}(\%)$ & 29 & 25 & 30 & 30 & 23 & 26 & 20 \\
\hline $\mathrm{H}_{2} \mathrm{~S}\left(\mathrm{ppm}_{\mathrm{v}}\right)$ & 270 & 350 & 117 & 276 & 290 & 259 & 284 \\
\hline
\end{tabular}

$\mathrm{CH}_{4}, \mathrm{CO}_{2}$ and $\mathrm{H}_{2} \mathrm{~S}$ concentrations obtained on day 3 suggest the establishment of a methanogenic phase since the beginning of the experiment for all treatments under evaluation, favored by the anaerobic conditions established in the biodigesters' start up. The values of methane concentration increased from the $3^{\text {rd }}$ to the $50^{\text {th }}$ day and remained over $58 \%$ in all mixtures under analysis, both at the beginning and at the end of the BMP tests (Table 4). The highest $\mathrm{CH}_{4}$ concentration obtained was with mixture $1 \mathrm{~g}_{\mathrm{vs}}$ OFMSW: $1 \mathrm{~g}_{\mathrm{vs}}$ swine manure on day $50\left(\mathrm{CH}_{4}=80 \%\right) . \mathrm{CO}_{2}$ concentrations were between 20 and 30\% in all mixtures under analysis, both at the beginning and at the end of the BMP tests.

Initial and final $\mathrm{H}_{2} \mathrm{~S}$ concentrations were between 259 and 290 ppmv, except for the mixture $1 g_{v s}$ OFMSW: $1 g_{v s}$ swine manure, which presented the lowest final $\mathrm{H}_{2} \mathrm{~S}$ concentration, 117 ppm. Such reduction in the $\mathrm{H}_{2} \mathrm{~S}$ concentration occurred simultaneously to the increase in the $\mathrm{CH}_{4}$ concentration (reaching $80 \%$ ), due to the acceleration in the production of organic acids during the acid phase, prior to the methanogenic phase. When the methanogenic phase advances, acids (such as $\mathrm{H}_{2}$, precursor of $\mathrm{H}_{2} \mathrm{~S}$ ) are converted into $\mathrm{CH} 4$ and $\mathrm{CO} 2$ (Schirmer et al., 2014; TchobanoglouS, Theisen and Vigil, 1993). The lowest $\mathrm{H}_{2} \mathrm{~S}$ concentration $\left(=117 \mathrm{ppm}_{\mathrm{v}}\right)$ revealed a medium with $\mathrm{pH}$ closer to neutrality (5.25) and higher alkalinity (4.99 $\mathrm{g}_{\mathrm{CaCO} 3 .} \mathrm{L}^{-1}$, Table 2 ), which contributed to the anaerobic co-digestion, resulting in higher $\mathrm{CH}_{4}$ concentration and higher volume of biogas generated (Figure 1).

It is known that the $\mathrm{H}_{2} \mathrm{~S}$ concentrations tend to reduce after the anaerobic digestion, due to the medium $\mathrm{pH}$, i.e., in acid conditions, the sulphur compounds prevail in the molecular form $\left(\mathrm{H}_{2} \mathrm{~S}\right)$, while in basic conditions the $\mathrm{H}_{2} \mathrm{~S}$ formation is inhibited, with the prevalence of sulphide ionized forms (Gostelow and Parsons, 2001). The 
reduction in de $\mathrm{H}_{2} \mathrm{~S}$ concentrations was not observed in the mixtures containing OFMSW and cattle manure. In such cases, the final $\mathrm{pH}$ was $4.58\left(1 \mathrm{~g}_{\mathrm{vs}}\right.$ OFMSW: $1 \mathrm{~g}_{\mathrm{vs}}$ cattle manure) and 3.9 ( $3 \mathrm{~g}_{\mathrm{vs}}$ OFMSW:1 $\mathrm{g}_{\mathrm{vs}}$ cattle manure, Table 2). Final $\mathrm{H}_{2} \mathrm{~S}$ concentrations are close to the values obtained by Schirmer et al. (2014) ( $\sim 300$ ppm $\left._{v}\right)$, and higher than the $50 \mathrm{ppm}_{\mathrm{v}}$ measured by Crovador (2014). The high final $\mathrm{H}_{2} \mathrm{~S}$ concentration might also be ascribed to the possible presence of sulphur recalcitrant compounds in the animal manure, coming from the food andor chemical additives (as previously mentioned ).

\section{CONCLUSIONS}

This study evaluated the biogas generation potential of the fresh organic fraction of municipal solid wastes inoculated with swine manure and cattle manure, based on the volatile solids content, through biochemical methane potential tests. Both the OFMSW and the swine manure and cattle manure presented high biodegradability potential in terms of volatile solids, with values reaching $93 \%$ for the OFMSW.

During the BMP tests with different mixtures of OFMSW, swine manure and cattle manure, the COD, which measures indirectly the amount of organic matter in the material, showed high percentage reduction (e.g. 92\% for the mixture $3 \mathrm{~g}_{\mathrm{vs}}$ OFMSW:1 $\mathrm{g}_{\mathrm{vs}}$ cattle manure). However, in this study higher COD values did not mean higher volume of biogas generated. The percentages of volatile solids reductions (from $5.5 \%$ to $11.4 \%$ ) were relatively low, indicating the existence of substrates that can be degraded, therefore, generate biogas even after the 50 days of digestion under investigation. Among the physico-chemical parameters evaluated, $\mathrm{pH}$ was a limiting parameter for the anaerobic digestion of OFMSW and manures being analyzed. At the end of the BMP tests, values of $\mathrm{pH}$ lower than neutrality were obtained in all treatments. The formation of VFA during the biodigestion might have acidified the medium and inhibited the organic matter complete conversion into biogas.

Regarding biogas generation, it can be considered representative on the first few days of digestion, as already reported by several authors. The mixture that obtained the best performance in terms of volume of biogas generated was $1 \mathrm{~g}_{\mathrm{vs}}$ OFMSW: $1 \mathrm{~g}_{\mathrm{vs}}$ swine manure. At the end of 50 days, this mixture accumulated higher volume of biogas (60.4 mL.g.g ${ }^{-1}$ or $\left.22 \mathrm{~mL} \cdot \mathrm{gOFMSW}^{-1}\right)$. 
$\mathrm{CH}_{4}, \mathrm{CO}_{2}$ and $\mathrm{H}_{2} \mathrm{~S}$ concentrations obtained during BMP tests suggest the establishment of a methanogenic phase since the beginning of the experiment for all treatments under evaluation. The values of $\mathrm{CH}_{4}$ concentration increased throughout the period of analysis, and were over $58 \%$ for all mixtures analyzed, both at the beginning and at the end of the BMP tests. The $\mathrm{CH}_{4}$ concentration peaked at $80 \%$, also for the mixture $1 \mathrm{~g}_{\mathrm{vs}}$ OFMSW: $1 \mathrm{~g}_{\mathrm{vs}}$ swine manure. The lowest $\mathrm{H}_{2} \mathrm{~S}$ concentration revealed a medium with $\mathrm{pH}$ closer to neutrality and higher alkalinity, which contributed to the anaerobic co-digestion, resulting in higher $\mathrm{CH}_{4}$ concentration and higher volume of biogas generated.

\section{ACKNOWLEDGMENTS}

The authors are thankful to Fundação Araucária do Paraná (Araucaria Foundation in the State of Parana) and Secretaria de Estado da Ciência, Tecnologia e Ensino Superior do Paraná (SETI) (State Secretary for Sciences, Technology and Higher Education) as well as the Coordenação de Aperfeiçoamento de Pessoal de Nível Superior (CAPES) (Coordination for the Improvement of Higher Education Personnel, Grant \#88881.030497/2013-01) - Brazil, under the Programa Ciência Sem Fronteiras (CsF) (Science Without Borders), for the financial support.

\section{REFERENCES}

Abbasi, T., Tauseef, S. M., Abbasi, S. A. (2012) "Anaerobic digestion for global warming control and energy generation - An overview", Renewable and Sustainable Energy Reviews, vol. 16, n. 05, pp. 3228-3242.

Alcântara, P. B. (2007) "Avaliação da influência da composição de resíduos sólidos urbanos no comportamento de aterros simulados", PhD Thesis (Civil Engineering Department), Federal University of Pernambuco, Recife, Brazil. [In Portuguese]

Alcaya, E.; Demirer, G. N. (2011) "Anaerobic mesophilic co-digestion of sugar-beet processing wastewater and beet-pulp in batch reactors", Renewable Energy, vol. 36, n. 03, pp. 971-975.

Álvarez, J. A.; Otero, L.; Lema, J. M. (2010) "A methodology for optimising feed composition for anaerobic co-digestion of agro-industrial wastes", Bioresource Technology, vol. 101, n. 04, pp.1153-1158.

Andreoli, C. V.; Ferreira, A. C.; Chernicharo, C. A.; Borges, E. S. M. (2003) "Secagem e higienização de lodos com aproveitamento de biogás”, In: Cassini, S. T. (Ed.), 
Digestão de resíduos sólidos orgânicos e aproveitamento do biogás, Rio de Janeiro: ABES, Rima, pp. 121-165. [In Portuguese]

Angelidaki, I.; Alves, M.; Bolzonella, D.; Borzacconi, L.; Campos, J. L.; Guwy, A. J.; Kalyuzhnyi, S.; Jenicek, P.; Van Lier, J. B. (2009) "Defining the biomethane potential (BMP) of solid organic wastes and energy crops: a proposed protocol for batch assays", Water Science \& Technology, vol. 59, n. 05, pp. 927-934.

APHA, AWWA, WEF (1999) "Standard Methods for the Examination of Water and Wastewater", 20ª ed., Washington, D.C.

ABNT - Associação Brasileira De Normas Técnicas (2004) 'NBR 10007: Amostragem de resíduos sólidos". Rio de Janeiro: ABNT. [In Portuguese]

Barcelos, B. R. de. (2009) "Avaliação de Diferentes Inóculos na Digestão Anaeróbia da Fração Orgânica de Resíduos Sólidos Domésticos”, Master Thesis (Civil and Environmental Engineering Department), University of Brasilia, Brasilia, Brazil. [In Portuguese]

Brasil (2012). Ministério do Meio Ambiente, "Plano Nacional de Resíduos Sólidos", Brasília: MMA, 103p. [In Portuguese]

Brasil (2016). Ministério das Cidades, Secretaria Nacional de Saneamento Ambiental, "Sistema Nacional de Informações sobre Saneamento: diagnóstico do manejo de resíduos sólidos urbanos - 2014”. Brasília: MCIDADES.SNSA, 154p. [In Portuguese]

Browne, J. D.; Murphy, J.D. (2013) "Assessment of the resource associated with biomethane from food waste", Applied Energy, vol.104, pp.170-177.

Browne, J. D.; Allen, E.; Murphy, J.D. (2014) "Assessing the variability in biomethane production from the organic fraction of municipal solid waste in batch and continuous operation”, Applied Energy, vol. 128, pp.307-314.

Cabbai, V.; Ballico, M.; Aneggi, E.; Goi, D. (2013) "BMP tests of source selected OFMSW to evaluate anaerobic codigestion with sewage sludge", Waste Management, vol. 33, n. 07, pp.1626-1632.

Cabral, A. R.; Capanema, M. A.; Gebert, J.; Moreira, J. F.; Jugnia, L. B. (2010) "Quantifying microbial methane oxidation efficiencies in two experimental landfill biocovers using stable isotopes”, Water, Air, \& Soil Pollution, vol. 209, pp. 157-172.

Chen, J. L.; Ortiz, R.; Steele, T.W.J.; Stuckey, D. C. (2014) "Toxicants inhibiting anaerobic digestion: A review”, Biotechnology Advances, vol .32, n. 08, pp.1523-1534.

Chen, Y.; Cheng, J. J.; Creamer, K. S. (2008) "Inhibition of anaerobic digestion process: a review", Bioresource Technology, vol. 99, n. 10, pp. 4044-4064.

Crovador, M. I. C. (2014) "Potencial de geração de biogás a partir da fração orgânica de resíduos sólidos urbanos", Master Thesis (Master of Science in Bioenergy), Midwest State University, Guarapuava, Brazil. [In Portuguese]

Decottignies, V.; Galtier, L.; Lefebvre, X.; Villerio, T. (2005) "Comparison of analytical methods to determine the stability of municipal solid waste and related wastes", In: Proceedings Sardinia, Tenth International Waste Management and Landfill Symposium, Cagliari, Italy. 
El-Mashad, H.M., Zhang, R. (2010) "Biogas production from co-digestion of dairy manure and food waste", Bioresource Technology, vol. 101, n. 11, pp. 4021-4028.

Esposito, G., Frunzo, L., Giordano, A., Liotta, F., Panico, A., Pirozzi, F. (2012a) "Anaerobic co-digestion of organic wastes", Rev. Environmental Science Biotechnology, vol. 11, n. 04, pp. 325-341.

Esposito, G.; Frunzo, L.; Liotta, F.; Panico, A.; Pirozzi, F. (2012b) "Bio-methane potential tests to measure the biogas production from the digestion and co-digestion of complex organic substrates", The Open Environmental Engineering Journal, vol. 5, pp.1-8.

Georgacakis, D.; Sievers, D. M.; Iannotti, E. L. (1982) "Buffer stability in manure digesters", Agricultural Wastes, vol. 4, n. 6, pp. 427-441.

Gostelow, P.; Parsons, S. A. (2001) "Hydrogen sulphide measurement”, In: Stuetz, R.; Frechen, F.B. (Ed.) Odours in wastewater treatment: Measurement, modelling and control. London: IWA Publishing, pp. 120-129.

Guarapuava - Prefeitura Municipal (2011) "Plano municipal de saneamento básico município de Guarapuava/PR - $1^{\text {a }}$ edição (versão final)". Available at: < http://www.guarapuava.pr.gov.br/wp-content/uploads/pms-guarapuava-verfinal.pdf>.

Accessed: 12 May 2014. 150p. [In Portuguese]

Hansen, T. L.; Schmidt, J. E.; Angelidaki, I.; Marca, E.; Jansen, J. C.; Mosbaek, H. and Christensen, T. H. (2004) "Method for determination of methane potentials of solid organic waste", Waste Management, vol. 24, n. 04, pp. 393-400.

Hessami, M.-A.; Christensen, S.; Gani, R. (1996) “Anaerobic Digestion of Household Organic Waste to Produce Biogas", Renewable Energy, vol. 09, n. 01-04, pp. 954-957.

IBAM. Instituto Brasileiro de Administração Municipal (2001) "Gestão Integrada de Resíduos Sólidos - Manual Gerenciamento Integrado de Resíduos Sólidos”. Rio de Janeiro: IBAM, 200p. [In Portuguese]

IBGE - Instituto Brasileiro de Geografia e Estatística (2002) "Pesquisa nacional de saneamento básico 2000". Rio de Janeiro: IBGE. Available at: $<$ http://www.ibge.gov.br/home/estatistica/populacao/condicaodevida/pnsb/pnsb.pdf $>$.

Accessed: 12 Oct. 2014. 397p. [In Portuguese]

Igoni, A. H.; Ayotamuno, M. J.; Eze, C. L.; Ogaji, S. O. T. And Probert, S. D. (2008) "Designs of anaerobic digesters for producing biogas from municipal solid-waste", Applied Energy, vol. 85, n. 06, pp. 430-438.

Imre, E.; Kovács, K. L.; Bagi, Z.; Ács, N.; Perei, R. K.; Bartha, I.; Trang P. Q.; Telekes, G. (2009) "Biotechnological methods to increase landfill gas production". In: Proceedings Sardinia, Twelfth International Waste Management And Landfill Symposium, Cagliari, Italy.

Karhadkar, P. P.; Audic, J.-M.; Faup, G. M.; Khanna, P. (1987) "Sulfide and sulfate inhibition of methanogenesis", Water Research, vol. 21, n. 09, pp. 1061-1066.

Kelly, R. J. (2002) "Solid waste biodegradation enhancements and the evaluation of analytical methods used to predict waste stability", Master Thesis (Master of Science in 
Environmental Science and Engineering), Faculty of Virginia Polytechnic Institute and State University, Blacksburg, United States.

Labatut, R. A.; Angenent, L. T.; Scott, N. R. (2011) "Biochemical methane potential and biodegradability of complex organic substrates", Bioresource Technology, vol. 102, n. 03, pp. 2255-2264.

Lapp, H. M.; Schulte, D. D.; Sparling, A. B.; Buchanan, L. C. (1975) "Methane production from animal wastes. 1. Fundamental considerations". Canadian Agricultural Engineering, vol. 17, n. 02, pp. 97-102.

Lastella, G.; Testa, C.; Cornacchia, G.; Notornicola, M.; Voltasio, F.; Sharma, V.K. (2002) "Anaerobic digestion of semi-solid organic waste: biogas production and its purification”, Energy Conversion and Management. vol. 43, n. 01, pp. 63-75.

Mata-Alvarez, J.; Macé, S.; Llabrés P. (2000) “Anaerobic digestion of organic solid wastes. An overview of research achievements and perspectives", Bioresource Technology, vol. 74, n. 01, pp. 3-16.

Mata-Alvarez, J.; Dosta, J.; Macé, S.; Astals, S. (2011) "Codigestion of solid wastes: a review of its uses and perspectives including modelling", Critical Reviews in Biotechnology, vol. 31, n. 02, pp. 99-111.

Mata-Alvarez, J.; Dosta, J.; Romero-Güiza, M.S.; Fonoll, X.; Peces, M.; Astals, S. (2014) "A critical review on anaerobic co-digestion achievements between 2010 and 2013”, Renewable and Sustainable Energy Reviews, vol. 36, pp. 412-427.

Mshandete, A.; Kivaisi, A.; Rubindamayugi, M.; Mattiasson, B. (2004) "Anaerobic batch co-digestion of sisal pulp and fish waste", Bioresource Technology, vol. 95, n. 01, pp. 19-24.

O’Leary, P. R.; Tchobanoglous, G. (2002) "Landfilling”, In: Tchobanoglous, G.; Kreith, F. (Ed.). Handbook of solid waste management. 2. ed. New York: Mcgraw-hill, pp. 14.1-14.93

Owen, W. F.; Stuckey, D. C.; Healy, J. B.; Young, L. Y.; Mccarty, P.L. (1979) "Biossay for monitoring biochemical methane potential and anaerobic toxicity", Water Research, vol. 13 , n. 06 , pp. $485-492$.

Parawira, W.; Murto, M.; Zvauya, R.; Mattiasson, B. (2004) "Anaerobic batch digestion of solid potato waste alone and in combination with sugar beet leaves", Renewable Energy, vol. 29, n. 11, pp.1811-1823.

Rajagopal, R.; Massé, D. I.; Singh, G. (2013) "A critical review on inhibition of anaerobic digestion process by excess ammonia", Bioresource Technology, vol. 143, September, pp. 632-641.

Redon, E.; Lornage, R.; Lagier, T.; Hebe, I. (2005) "Measurement and comparison of different stability parameters during a mechanical biological pretreatment before landfilling”. In: Proceedings Sardinia, Tenth International Waste Management and Landfill Symposium, Cagliari, Italy.

Richard, T. L. (1992) "Municipal solid waste composting: physical and biological processing", Biomass and Bioenergy, vol. 03, n. 3-4, pp. 163-180. 
Sakar, S.; Yetilmezsoy, K.; Kocak, E. (2009) "Anaerobic digestion technology in poultry and livestock waste treatment - a literature review", Waste Management \& Research, vol. 27, n. 01, pp. 3-18.

Schirmer, W. N.; Jucá, J. F. T.; Schuler, A. R. P.; Holanda, S.; Jesus, L. L. (2014) "Methane production in anaerobic digestion of organic waste from Recife (Brazil) Landfill: evaluation in refuse of different ages". Brazilian Journal of Chemical Engineering, vol. 31, n. 02, pp. 373-384.

Siles, J. A.; Brekelmans, J.; Martín, M. A., Chica, A. F., Martín, A. (2010) "Impact of ammonia and sulphate concentration on thermophilic anaerobic digestion", Bioresource Technology, vol. 101, n. 23, pp. 9040-9048.

Sims, R. E. H.; Schock, R. N.; Adegbululgbe, A.; Fenhann, J.; Konstantinaviciute, I.; Moomaw, W.; Nimir, H. B.; Schlamadinger, B.; Torres-Martínez, J.; Turner, C.; Uchiyama, Y.; Vuori, S. J. V.; Wamukonya, N.; Zhang, X. (2007) "Energy supply", In Climate Change 2007: Mitigation. Contribution of Working Group III to the Fourth Assessment Report of the Intergovernmental Panel on Climate Change [B. Metz, O.R. Davidson, P.R. Bosch, R. Dave, L.A. Meyer (eds)], Cambridge University Press, Cambridge, United Kingdom and New York, NY, USA.

Souza, M. E. (1984) "Fatores que Influenciam a Digestão Anaeróbia", Revista DAE, vol. 44, n. 137, pp. 88-94. [In Portuguese]

Tchobanoglous, G., Theisen, H., Vigil, S. A. (1993) "Integrated solid waste management: engineering principles and management issues", New York: McGrawHill, 978p.

USEPA - US Environmental Protection Agency (1991) "Air emissions from municipal solid waste landfills - Background information for proposed standards and guidelines", Publication EPA-450/3-90-011a, North Carolina, United States.

Wang, X.; Yang, G.; Feng, Y.; Ren, G.; Han, X. (2012) "Optimizing feeding composition and carbon-nitrogen ratios for improved methane yield during anaerobic co-digestion of dairy, chicken manure and wheat straw", Bioresource Technology, vol. 120, September, pp. 78-83.

Ward, A.J.; Hobbs, P.J.; Holliman, P. J.; Jones, D. L. (2008) "Optimisation of the anaerobic digestion of agricultural resources", Bioresource Technology, vol. 99, n. 17, pp. $7928-7940$.

WEC - World Energy Council (2013) "World Energy Resources - 2013 Survey". London, 468p.

Xie, S.; Lawlor, P. G.; Frost, J. P.; Hu, Z.; Zhan, X. (2011) "Effect of pig manure to grass silage ratio on methane production in batch anaerobic co-digestion of concentrated pig manure and grass silage", Bioresource Technology, vol. 102, n. 10, pp. 5728-5733.

Yenigün, O.; Demirel, B. (2013) "Ammonia inhibition in anaerobic digestion: A review”, Process Biochemistry, vol. 48, n. 5-6, pp. 901-911.

Yin, D.; Liu, W.; Zhai, N.; Yang, G.; Wang, X.; Feng, Y.; Ren, G. (2014) "Anaerobic digestion of pig and dairy manure under photo-dark fermentation condition", Bioresource Technology, vol. 166, pp. 373-380. 
Zhang, P.; Zeng, G.; Zhang, G.; Li, Y.; Zhang, B.; Fan, M. (2008) “Anaerobic codigestion of biosolids and organic fraction of municipal solid waste by sequencing batch process", Fuel Processing Technology, vol. 89, n. 04, pp. 485-489.

Zhang, C.; Su, H.; Baeyens, J.; Tan, T. (2014) "Reviewing the anaerobic digestion of food waste for biogas production", Renewable and Sustainable Energy Reviews, vol. 38, October, pp. 383-392. 